\title{
Determination of Zinc Content in Commercial Toothpaste Samples in Nigeria by Atomic Absorption Spectrophotometric Method
}

\author{
James Okwudiri Ogidi and Matthias Onyebuchi Agbo* \\ Department of Pharmaceutical \& Medicinal Chemistry, University of Nigeria, Nsukka 41000 Enugu State, Nigeria. \\ *Corresponding Author Email: matthias.agbo@unn.edu.ng \\ Received 20 August 2019, Revised 12 March 2021, Accepted 26 March 2021
}

\begin{abstract}
Zinc as its citrate or sulphate salt is added to some toothpaste as a bactericide to reduce the presence of bacteria in the mouth. These bacteria can form plaque or produce acids which cause dental decay and halitosis. Zinc salt is added at amounts which are enough to show activity against oral bacteria without causing toxicity to the user. Five commercial samples of different brands of toothpaste (TP-A, TP-B, TP-C, TP-D and TP-E) were purchased from different pharmacy stores in Ogige and Eko markets, Nigeria and analysed for the presence of zinc using atomic absorption spectrophotometric method. The samples were digested with deionized water and $\mathrm{HNO}_{3}$, centrifuged and filtered. The absorbance of the supernatants obtained was read with a spectrophotometer. Calibration curves for zinc sulphate and zinc citrate were obtained with regression $\left(R^{2}\right)$ values of 0.9992 and 0.9973 , respectively. The equation obtained from the curves used in determining the content of zinc in the samples. The zinc content $(\% w / w)$ of samples was determined to be $0.8467 \%, 0.8127 \%, 0.0119 \%, 0.0188 \%$ and $0.0305 \%$, respectively. These values were well below the maximum permissible level of zinc in toothpaste samples but were within the upper limit for daily zinc intake.
\end{abstract}

Keywords: Toothpaste, Zinc content, Dental decay, Digestion, Absorption Spectrophotometry.

\section{Introduction}

Oral hygiene is one of the major concerns in human personal hygiene and is maintained using dentifrices such as toothpastes and mouthwashes [1, 2]. Toothpastes are gel-like dentifrices used with a toothbrush to clean and maintain the aesthetics and health of teeth [3]. Toothpastes serve as agents that help remove dental plaques and food residues, prevent halitosis (bad mouth odour), and promote teeth whitening [1]. To satisfy the above requirements, various active and inactive ingredients are incorporated in the toothpastes during their manufacture. These ingredients are classified based on their function in the formulation and include; detergents like sodium lauryl sulphate; binding agents like carrageenan and xanthan gum; abrasives like calcium carbonate and calcium pyrophosphate; humectants like sorbitol and propylene glycol; and fluorides like sodium fluoride and tin fluoride [4]. Flavours, preservatives, colorants and antibacterial agents like triclosan, zinc salts (zinc chloride, zinc citrate, zinc sulphate) are also incorporated during formulations to improve the quality and functionality by giving palatable flavours, preventing microbial degradation, improving product colour and inhibiting microbial attack on gums. The 
toothpaste market over time has grown with different brands competing to gain considerable market share. Nigeria alone has over thirty commercial toothpaste brands; some of the more common ones include, Close-up, Pepsodent, Sensodyne, Daily Need, Oral-B, Mentadent-p, Colgate, Aquafresh, Listerine, Minta and Macleans, to mention but a few [5].

Different toothpaste brands come with different indications targeted at specific users; hence whitening toothpastes, anti-decay toothpastes, desensitizing toothpastes, antiplaque toothpastes etc., are common [6]. Dental decay is caused by the formation of acid by certain mouth bacteria as a result of food particles that remains in the mouth, which dissolves the hard enamel coating $[7,8]$. This process is worsened since the bacteria feed on organic material in the inner portion of the teeth [9]. To prevent this bacterial catalysed mouth decay and improve oral health, most toothpaste brands incorporate antimicrobial agents like triclosan and zinc salts in their formulations [10, 11]. Zinc is added in toothpaste formulations in the form of chloride, citrate or sulphate salts [12]. Reports suggested that excess amounts of zinc may have harmful effects on the enamel [13]. Still, zinc ions are generally considered safe since it is an essential nutrient required for numerous physiological functions [14]. No stringent regulations exist for zinc salts that should be incorporated in cosmetic products like toothpastes. Although, European regulatory bodies require that the heavy metal content of toothpastes should not exceed 20 ppm [15]. Dental plaque is recognized as the etiological factor responsible for dental caries and periodontal diseases. Cases of dental caries and periodontal diseases among school children in Nigeria have been reported [1617]. Thus, to ensure the validity of claims made about the zinc content of toothpaste brands, we carried out a quantitative analysis to determine the level of zinc in some commercial toothpaste sold in Nigeria.

\section{Materials and Methods Reagents}

Zinc citrate, concentrated $\mathrm{HNO}_{3}$, and zinc sulphate were purchased from SigmaAldrich, Germany.

\section{Instrumentation}

The samples were analysed employing atomic absorption spectrometer model AA7000, ROM version 1.01, S/N A3066470070 controlled by Winlab 32 for AA software, running under Microsoft windows. Multielements Lumina hollow cathode lamps were used with a high sensitivity nebulizer. Analysis was carried out at wavelength 213.8 $\mathrm{nm}$ with a slit width of $0.7 \mathrm{~nm}$. The type of flame employed was the air-acetylene flame in the ratio of 15:2 Table 1 .

Table 1. Product information leaflet of the toothpaste samples.

\begin{tabular}{cccccc}
\hline Code & $\begin{array}{c}\text { Batch } \\
\text { Number }\end{array}$ & $\begin{array}{c}\text { NAFDAC } \\
\text { Number }\end{array}$ & ing Date & $\begin{array}{c}\text { Expiry } \\
\text { Date }\end{array}$ & $\begin{array}{c}\text { Country } \\
\text { of } \\
\text { Manufact } \\
\text { ure }\end{array}$ \\
\hline TP-A & 52114 NLSL & --- & JUN. 2016 & DEC. 2019 & $\begin{array}{c}\text { South } \\
\text { Africa }\end{array}$ \\
TP-B & 90996439 & $02-6769$ & MAY. 2017 & APR. 2019 & Germany \\
TP-C & 0352A & --- & NOV. 2016 & NOV. & USA \\
TP-D & 173553 & $02-7346$ & SEP. 2017 & $\begin{array}{c}\text { MAR. } \\
2019\end{array}$ & Nigeria \\
TP-E & HAA7W1 & --- & MAY. 2017 & JUL. 2020 & Poland \\
\hline
\end{tabular}

\section{Sample Collection}

Five different trademarked toothpastes, containing zinc as it's citrate or sulphate salt were randomly purchased from Ogige market in Nsukka (coded: TP-A, TP-D, TP-E) and Eko market in Lagos, Nigeria (coded: TP-B, TP-C) (Table 2). The five samples were conventional toothpastes. 
Table 2. Instrument settings for the spectrophotometer (AA-7000, ROM version 1.01).

\begin{tabular}{cc}
\hline Parameters & Zinc \\
\hline Wavelength & $213.8 \mathrm{~nm}$ \\
Band pass & $0.7 \mathrm{~nm}$ \\
Lamp Current & $8 \mathrm{~mA}$ \\
Flame type & air-acetylene \\
Fuel flow rate & $2.0 \mathrm{~L} / \mathrm{min}$ \\
Measurement Time & $5 \mathrm{secs}$ \\
Replicates & 3 \\
\hline
\end{tabular}

\section{Digestion of Samples}

The digestion of the toothpaste samples was done as previously reported with slight modification [15]. Briefly, $1.0 \mathrm{~g} \mathrm{( \pm}$ $0.001 \mathrm{~g}$ ) of each toothpaste sample was weighed and transferred into a $100 \mathrm{~mL}$ beaker; $50 \mathrm{~mL}$ of de-ionized water was added and digested with $5 \mathrm{~mL}$ of concentrated $\mathrm{HNO}_{3}$ at a reduced temperature on a hot plate in a fume cupboard for $3 \mathrm{~h}$ until no brown fumes were observed. The solution was cooled, centrifuged for $5 \mathrm{~min}(3500 \mathrm{rpm})$ and the supernatant transferred to a $100 \mathrm{~mL}$ volumetric flask and made up to volume with de-ionized water.

\section{Preparation of Standards}

$125 \mathrm{mg}$ of zinc salt (zinc sulphate and zinc citrate) was weighed and dissolved in $1 \mathrm{~L}$ of de-ionized water to obtain a standard stock solution of $125 \mathrm{mg} / \mathrm{L}(125 \mathrm{ppm})$ of zinc salt. $10 \mathrm{~mL}$ of the standard stock solution was transferred into a $100 \mathrm{~mL}$ volumetric flask and made up to mark with de-ionized water to obtained a diluted stock solution. 10 $\mathrm{mL}$ of the resulting diluted stock solution was further diluted 10 folds. $0,5,10,15,20$ and $25 \mathrm{~mL}$ aliquots of the 100 folds diluted stock solution were each transferred to various volumetric flasks and diluted to $100 \mathrm{~mL}$ with de-ionized water to obtain the calibration series with concentrations ranging from 0-1 ppm.

\section{Sample Analysis}

The zinc content of the samples was determined using Atomic Absorption Spectrometer model AA-7000 at $213.8 \mathrm{~nm}$. The analysis was done in triplicates and the ppm concentration of zinc interpolated from the standard curves (Fig. 1-2). The percentage zinc content in each sample was then calculated using the formula:

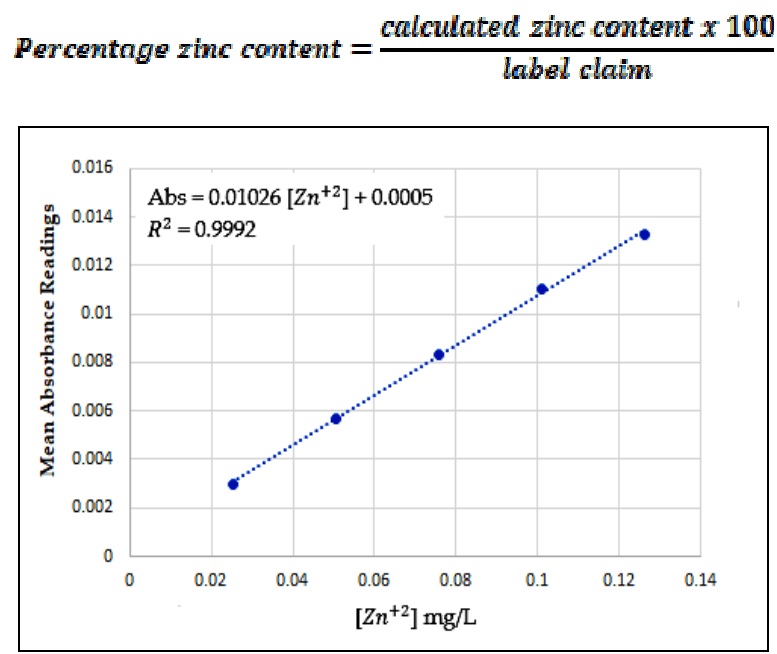

Figure 1. Calibration curve for $\left[\mathrm{Zn}^{+2}\right]$ in zinc sulphate standards

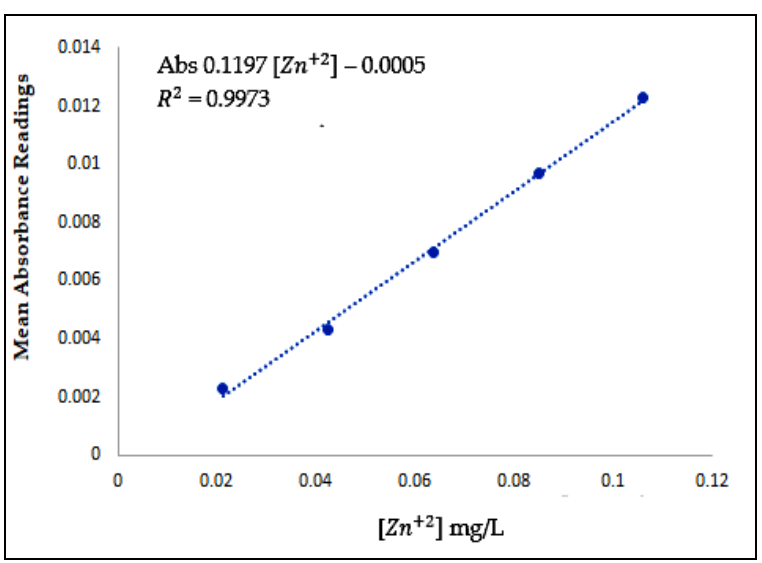

Figure 2. Calibration curve for $\left[\mathrm{Zn}^{+2}\right]$ in zinc Citrate standards

\section{Results and Discussion}

Atomic absorption spectroscopy (AAS) is used for the quantification of trace levels of metals in a wide variety of samples [18-19]. Lewen et al., [20] has reported that 
AAS is used in the pharmaceutical industry for the determination of trace elements in pharmaceutical samples like zinc in zinc insulin suspension; copper and iron in ascorbic acid; silver in cisplatinum and magnesium, mercury and zinc in water used for diluting haemodialysis solution. Zinc is a trace element that helps maintain human health, especially in the metabolism of many enzymes and proteins [21-22]. In the oral cavity, zinc is present in the dental hard tissues and saliva [22]. The report showed that zinc is effective against common prevalent oral health problems such as dental caries, gingivitis, periodontitis and malodour [23].

The zinc content in the samples was determined as the percentage weight per weight $(\% w / w)$ of $\mathrm{Zn}^{+2}$ to validate their label claims and ensure that they fell within safety limits. It was observed that the zinc content of the samples was within the allowed zinc content in their label claims. The zinc content of samples $(\% \mathrm{w} / \mathrm{w})$ was determined to be 0.8467, 0.8127, 0.0119, 0.0188 and 0.0308 for TP-A, TP-B, TP-C, TP-D and TP-E, respectively, corresponding to $42.34 \%$, $40.64 \%$ and $0.60 \%$, of the label claim (2\%), while the zinc content of samples TP-D and TP-E was determined to be $9.40 \%$ and $15.40 \%$ of the label claim $(0.2 \%)$ (Table 3 \& 4).

Table 3. Zinc contents in the toothpaste samples.

\begin{tabular}{ccc}
\hline Sample & $\begin{array}{c}{\left[\mathbf{Z n}^{+2}\right] \mathbf{m g} / \mathbf{L} \pm} \\
\text { SEM }\end{array}$ & {$\left[\mathbf{Z n}^{+2}\right](\% w / w)$} \\
TP-A & $84.67 \pm 1.83$ & 0.8467 \\
TP-B & $81.27 \pm 0.86$ & 0.8127 \\
TP-C & $1.19 \pm 0.06$ & 0.0119 \\
TP-D & $1.88 \pm 0.03$ & 0.0188 \\
TP-E & $3.08 \pm 0.02$ & 0.0308 \\
\hline
\end{tabular}

Zn content $\pm \operatorname{SEM}(\% w / w)$. Zinc sulphate in toothpaste $=2 \%(w / w)$; Zinc citrate in toothpaste $=0.2 \%(w / w)$.
Table 4. Calculated zinc content of the samples in comparison with label claims.

\begin{tabular}{cccc}
\hline Sample & $\begin{array}{c}\text { Label Claim } \\
(\boldsymbol{\%} \boldsymbol{w} \boldsymbol{w})\end{array}$ & $\begin{array}{c}\text { Calculated Zinc } \\
\text { content }(\boldsymbol{\%} \boldsymbol{w} \boldsymbol{w})\end{array}$ & $\begin{array}{c}\text { Percent of Label } \\
\text { Claim }\end{array}$ \\
\hline TP-A & $2 \%$ & 0.8467 & 42.34 \\
TP-B & $2 \%$ & 0.8127 & 40.64 \\
TP-C & $2 \%$ & 0.0119 & 0.60 \\
TP-D & $0.2 \%$ & 0.0188 & 9.40 \\
TP-E & $0.2 \%$ & 0.0308 & 15.40 \\
\hline
\end{tabular}

Zinc citrate has been reported to exhibit activity against oral bacteria at concentrations between $0.5-2 \%$, while zinc sulphate is effective at minimum concentrations of $0.2 \%$ [23-25]. However, the zinc contents in the assayed samples (TP-A and TP-B) were above the threshold concentration, while the zinc content of the other samples was below these threshold concentrations, indicating the possibility of reduced antibacterial efficacy by these samples.

The estimated daily zinc intake from samples TP-A, TP-B, TP-C, TP-D and TP-E were determined as $0.1164,0.1118,0.0016$, 0.026 and $0.042 \mathrm{mg} /$ day, respectively (Table 5). The obtained values were far below the upper limit for zinc intake ( $25 \mathrm{mg} /$ day) as stipulated by the European Scientific Committee on Consumer Safety (SCCS) [26], indicating a reduced possibility of zinc toxicity occurring from the daily use of these brands.

Table 5. Daily intake and percentage upper limit of zinc from toothpaste samples.

\begin{tabular}{cccc}
\hline Samples & $\begin{array}{c}\text { Zinc } \\
(\boldsymbol{\%} w / \boldsymbol{w})\end{array}$ & $\begin{array}{c}\text { Daily intake level } \\
(\mathbf{m g} / \text { day })\end{array}$ & $\begin{array}{c}\text { \% Upper } \\
\text { limit }\end{array}$ \\
\hline TP-A & 0.8467 & 0.1164 & 33.87 \\
TB-B & 0.8127 & 0.1118 & 32.51 \\
TP-C & 0.0119 & 0.0016 & 0.48 \\
TP-D & 0.0188 & 0.0026 & 0.75 \\
TP-E & 0.0308 & 0.0042 & 1.23 \\
\hline
\end{tabular}

Upper limit of zinc intake daily is $25 \mathrm{mg} /$ day;

$\%$ upper limit $=\frac{\text { zinc content }\left(\% \frac{v}{w}\right) \times 100}{25.0}$ 
The analysis of heavy metals present in toothpastes is always faced with a lot of challenges, such as developing an excellent method for the extraction of the metals for analysis into solution from the complex organic matrix of which toothpastes are composed . Although, successful method for the extraction of $\mathrm{Pb}, \mathrm{Sn}$ and $\mathrm{Hg}$ was developed, no feasible method has been developed for the analysis of zinc [27]. This could account for the remarkable low zinc contents of the analysed samples. The differences in the obtained zinc content of the samples (TP-C, TP-A, TP-B: 0.0119\%, $0.8467 \%, 0.8127 \%$, respectively) could also have arisen from the fact that the toothpastes are made by different companies and contain different ingredients, TP-C may have a more complex organic matrix than TP-A and TP-B, which then makes analysis of zinc more difficult in TP-C. Deviations were also observed between the zinc content in TP-D and TP-E, which could be explained by their different organic matrixes.

\section{Conclusion}

The determined zinc content of the five toothpaste brands was below their label claims and falls below the upper limit for daily zinc intake. Thus, our findings showed that continuous use of these toothpaste brands would not cause zinc toxicity. Their efficacy in inhibiting oral biofilms is reduced, making them less effective at preventing plaque and malodour. Due to the complex organic matrixes in toothpastes, the determined zinc contents of the toothpaste samples may be below their true contents. Thus, a more robust method for determining zinc in toothpaste using the atomic spectroscopic method is recommended.

\section{Conflict of Interest}

The authors declare that there is no conflict of interest.

\section{References}

1. V. Y Adam, S. A. Okeigbemen, O. Osagie and E. Oseghale, Nigerian Health J., 17 (2017) 19.

2. S. N Goryawala, P. Chavda, S. Udhani, N. V. Patha, S. Pathak and R. Ojha, J. Int. Soc. Prevent. Community Dent., 6 (2016) 115.

http://doi.org/10.4103/22310762.178750.

3. F. Lippert, Monogr. Oral Sci., 23 (2013) 1.

http://doi.org/10.1159/000350456.

4. E. Vranic, A. Lacevic, A. Mehmedagic and A. Uzonovic A, Bosnian J. Basic Med. Sci., 4 (2004) 51.

http://doi.org/10.17305/bjbms.2004.3362.

5. Nwachukwu, M.I. N. C. Duru, T.E. Ogbulie, I.O. Nwachukwu and C.C. Ibe, Int. J. Natural Appl. Sci., 2 (2010) 272. http://doi.org/ 10.4314/ijonas.v2i3.36103.

6. Maldupa, I. A. Brinkmane, I. Rendeniece and A. Mihailova, Baltic Dental Maxillofacial J., 14 (2012) 12. http://www.sbdmj.com/121/121-02.pdf.

7. N. Takahashi and B. Nyvad, J. Dental Res., 90 (2011) 294.

http://doi.org/10.1177/00220345103796 02.

8. R. Surarit, E. Benjavongkulchai and J. Svasti, Biochem. Edu., 22 (1994) 45. http://doi.org/10.1016/03074412(94)90173-2

9. A. O. Oyewale, J. Sci. Ind. Res., 64 (2005) 101.

http://www.cffet.net/project/topics/SB1. pdf.

10. M. Prasanth, Dental Res. J., 8 (2010) 85.

11. Hall, P. J. A. K. Green, C. P. Horay, S. de Brabander, T. J. Beasley, V. J. Cromwell, J. S. Holt and D, J. Savage, Int. Dental J., 53 (2003) 379.

http://doi.org/10.1111/j.1875595X.2003.tb00913. x 
12. P. Stadtler, German National J. 21. M. Hambidge, Nutr. J., 130 (2000) Stomatol., 84 (1987) 351. https://www.ncbi.nlm.nih.gov/pubmed/3 504658.

13. R. J. M. Lynch, Int. Dental J., 61 (2011) 46.

http://doi.org/10.1111/j.1875595X.2011.00049.x.

14. C. T. Walsh, H. H. Sandstead, A. S. Prasad, P. M. Newberne and P. J. Fraker, Environ. Health Perspect.102 (1994) 5. http://doi.org/10.1289/ehp.941025.

15. R. N. Rao and T. N. Rao, Indian J. Chem. Technol., 21 (2014) 238.

16. O. O. Sofola, M.O. Folayan and A. B. Oginni, Nigerian J. Clin. Pract, 17 (2014) 127.

http://doi.org/10.4103/1119-

3077.127419.

17. C. A. Akinyamoju, D. M. Dairo, I. A. Adeoye and A. O. Akinyamoju, Nigerian Postgrad. Med. J., 25 (2018) 239.

http://doi.org/ 10.4103/npmj.npmj_138_18.

18. A. D. Skoog, F. J. Holler and T. A. Nieman, Instrumental Analyses (5th ed.); (1998). 206, New York, USA: Harcourt Brace College Publishers.

19. B. Gouthami and R. N. Rao, Int. J. Basic Appl. Sci., 1 (2015) 37.

20. N. Lewen, J. Pharm. Biomed. Anal., 55 (2011) 653. http://doi.org/10.1016/j.jpba.2010.11.030.

22. Tayyaba, F. Z. B. Haji, A. Rahim, C. W. Lin and Z. Qamar, J. Pak. Med. Assoc., 66 (2016) 1019.

23. J. Moran, M. Addy, D. Corry, R. J. Newcombe J. Haywood, J. Clin. Periodontol., 28 (2001) 157.

http://doi.org/10.1034/j.1600051x.2001.028002157.x.

24. S. E. Adams, A. J. Theobald, N. M. Jones, M. G. Brading, T. F Cox, A. Mendez, D. M. Chesters, D. G. Gillam, C. Hall and J. Holt, Int. Dental J., 53 (2003) 398. http://doi.org/10.1111/j.1875595X.2003.tb00916. X.

25. R. Navada, H. Kumari, S. Le and J. Zhang, J. Clin. Dent., 19 (2008) 69.

26. U. Bernauer, L. Bodlin, L. Celleno, Q.M. Chaudhry, P-J. Coenraads, M. Dusinska, J. Ezendam, E. Gaffet, L.C. Galli, B.B. Granum, E. Panteri, V. Rogiers, C. Rousselle, M. Stepnik, T. Vanhaecke and S. Wijnhoven, SCCS Opinion on Water-soluble Zinc Salts used in Oral Hygiene ProductsSubmission I. (2017). Ffhal-01493462f. https://hal.archives-ouvertes.fr/hal01493462.

27. S. Popova, and A. Marinova, J. Univ. Chem. Technol. Metall., 42 (2007) 413. 